\title{
ALDONA KOBUS
}

Uniwersytet Mikołaja Kopernika w Toruniu

kobald@umk.pl

ORCID: oooo-0oo1-6646-8640

\section{Fan jako marka. O użyteczności fana dla przemysłu kulturowego}

\section{Fan as a brand: The usefulness of a fanboy for culture industry}

Anastasia Salter, Mel Stanfill, A Portrait of the Auteur as Fanboy. The Construction of Authorship in Transmedia Franchises, University Press of Mississippi, Jackson 2020.

DOI: 10.12775/LL.2.2021.009 | CC BY-ND 3.0 PL

W początkach formowania się fan studies na przełomie lat 8o. i 90. XX w. podstawowy przedmiot badań, czyli postać fana, był obiektem kulturowej i społecznej stygmatyzacji. Stereotypy na temat zdemaskulinizowanych dziwaków i rozhisteryzowanych nastolatek, potencjalnych sprawców przemocy, zaludniały medialną wyobraźnię. I chociaż tego rodzaju wyobrażenia nie zniknęły, praktyki fanowskie zostały stopniowo inkorporowane w struktury przemysłu kulturowego. Fani stali się cenioną, a nawet modelową grupą odbiorców - emocjonalnie zaangażowani, lojalni wobec marki, definiujący się przez kompulsywne praktyki w rodzaju kolekcjonerstwa i zbieractwa, stanowią idealny rynek zbytu dla popkulturowych treści. Postawa fanowska jest aktywnie kreowana przez koncerny medialne, a następnie pielęgnowana i odgórnie kontrolowana, tak by nie wy- 
mknęła się spod kontroli. Nobilitacja postaci fana ma bowiem charakter wybiórczy, dotyczy fandomu kultywującego, a nie transformującego, nie zachęca do krytycznego podejścia względem konsumowanego materiału ani do jego dalszych przekształceń. Idealnym konsumentem jest fan, a nie fanka. Tylko niektóre fanowskie praktyki okazały się korzystne dla przemysłu kulturowego i przez to znalazły swoje miejsce w kulturze głównonurtowej. Nobilitacja fana pociaggnęła za sobą szczególną konstrukcję autora-fana, czyli przedstawiciela przemysłu kulturowego, deklarującego fanowskie przywiązanie wobec produkowanych przez siebie treści (najlepszym przykładem jest reżyser i showranner stacji BBC, Steven Moffat, który zasłynął serią adaptacji klasyki literatury brytyjskiej i często określa siebie fanem tego, co adaptuje: Sherlocka Holmesa, czy Draculi; wiemy też, że działał aktywnie w fandomie Doktora Who zanim zaczął pracować w telewizji).

Należy tutaj odróżnić fana-autora, tworzącego teksty skierowane do wewnętrznego obiegu w społeczności fanowskiej (np. fanfiction Moffata w fandomie Doktora Who) od autora-fana, twórcy treści popkulturowych o komercyjnym charakterze, który legitymizuje się tożsamością fanowską w celu wzbudzenia określonych reakcji wśród odbiorców (zaufania, popularności itd.). Autor-fan w pierwszej kolejności jest przedstawicielem przemysłu, profesjonalistą, który jednak działa $\mathrm{w}$ fandomie lub deklaruje, że jest fanem. Fan-autor produkuje teksty kultury, które nie trafią do oficjalnego obiegu. Zgodnie z tą definicją przypadek objęcia oficjalną licencją tekstu kultury fanowskiej nie wystarcza, aby wykreować autora-fana, podobnie jak tworzenie tekstów zależnych w głównonurtowym obiegu (np. Neil Gaiman publikujący teksty zależne wobec prozy H.P. Lovecrafta czy Seth Grahame-Smith piszący Dumę $i$ uprzedzenie i zombie na podstawie kultowej powieści Jane Austen). Uwidacznia to, że autor-fan to bardzo szczególny przypadek w ramach twórczości popkulturowej. Co ciekawe, tego rodzaju twórcy często posiadają własne fandomy (m.in. Joss Whedon, Kevin Smith czy Zack Snyder, którzy mają wielbicieli nie tylko określonych tytułów, ale całej swojej twórczości, a tym samym swoich postaw twórczych, deklaracji autorskich i person publicznych). „Bycie fanem” stało się więc specyficzną marką twórców kultury popularnej, a strategie jej kreacji i cele, w jakich jest wykorzystywana, stanowią przedmiot badań Anastasi Salter i Mel Stanfill w monografii A Portrait of the Auteur as Fanboy. The Construction of Authorship in Transmedia Franchises.

Obie badaczki posiadają już znaczący dorobek, który stanowił podwaliny pod najnowszą monografię. Salter jest także współautorką Toxic Geek Masculinity in Media (2017), chociaż większość jej prac sytuuje się w nurcie game studies i badaniach literatury cyfrowej; Stanfill wydała w 2019 r. Exploiting Fandom: How the Media Industry Seeks to Manipulate Fans, jedną z kluczowych pozycji fantropologicznych ostatnich lat, a liczne artykuły zapewniły jej pozycję czołowego fantropologa obecnego pokolenia badaczy. Najnowsza publikacja stanowi zbiór dziesięciu case studies poświęconych różnym postaciom autora-fana. Stosując analizę dyskursu, badaczki przeanalizowały doniesienia prasowe, wywiady, kre- 
acje autorskie w mediach społecznościowych i elementy twórczości wybranych autorów-fanów w celu ustalenia, jak konstruowane jest autorstwo w przypadku twórców w różnym stopniu identyfikujących się z fandomem treści, które (współ)tworzą. Opisywani autorzy sytuują się w różnych pozycjach na spektrum wyznaczonym przez takie czynniki, jak autoidentyfikacja $\mathrm{z}$ fandomem medialnym oraz afirmatywny lub transformatywny stosunek do franczyzy, jaką kreują. Taka perspektywa pozwoliła badaczkom zaprezentować szeroki przekrój tożsamości i postaw autorów-fanów, ich odmienne podejścia do fandomu i różnorodnych narracji tożsamościowych, co naświetla stosunek kultury głównonurtowej do rozmaitych praktyk i aktywności fanowskich. W dobie gwałtownych przeobrażeń pozycji fana w kulturze praca Salter i Stanfill dostarcza potrzebnych narzędzi i kategorii analitycznych, których zastosowanie nie ogranicza się do badań nad autorstwem, chociaż i w tym polu można znaleźć cenne uwagi i refleksje.

Przykładem tego jest chociażby zwrócenie uwagi na performatywny wymiar autorstwa, które konstruuje się przez serię powtarzalnych gestów i działań, serię interakcji z instytucjami i aktorami przemysłu kulturowego oraz z fanami (s. XIV). Interakcje te mają na celu utwierdzenie autorskiej kontroli i władzy nad tekstem poprzez ustalenie dozwolonych ram i granic interpretacji. Tym samym podkreślone zostaje, że autorstwo jako instytucja społeczna ma nie tylko wysoce konstruktywny charakter (szczególnie autorstwo medialne, gdzie ustanawia się jeden podmiot autorski kosztem przemilczenia lub wymazania kreatywnego wkładu całej rzeszy twórczych podmiotów), ale jest też narzędziem dystrybucji władzy społecznej, elementem kulturowej hierarchii. Autorstwo ma także aspekt marketingowy, nosi znamiona marki czy logo, co okazuje się szczególnie ważne w dobie kulturowej konwergencji i rozproszenia treści w obrębie różnych mediów i platform dystrybucji. Performatywne autorstwo ma stanowić gwarancję spójności i jakości w obliczu owego rozproszenia, być rodzajem scalającego paratekstu (s. xv). Tutaj właśnie szczególnie uwidacznia się rola autora-fana, obdarzonego potencjałem promocyjnym (nazwisko, które przyciąga odbiorców, ponieważ gwarantuje zrozumienie ich potrzeb jako fanów) i afektywnym, stanowiącego $\mathrm{z}$ jednej strony obiekt fandomowego uwielbiania (twórca ukochanego tytułu), a z drugiej strony prezentującego się jako członek tego samego fandomu („fan taki, jak ja”), co stwarza poczucie więzi i iluzję wspólnej przestrzeni porozumienia czy wspólnych interesów. Autor-fan jest „jednym z nas”, tak samo jak ,jednym z nich”, sekretnym agentem wśród korporacyjnych dorobkiewiczów, który przedkłada dobro franczyzy nad potencjalne zyski i tym samym staje się znów gwarantem spójności i jakości. W serii case studies Salter i Stanfill demaskują marketingowy mit autora-fana zestawiając tego rodzaju przekonania z praktyką performatywnego konstruowania autorstwa przez konkretnych twórców.

Pierwszym przypadkiem jest Steven Moffat, typ fana uprawiającego gatekeeping, który aktywnie zachęca do partycypacji - pod warunkiem, że odbiorcy reprezentują dokładnie ten sam model „bycia fanem”, co on sam - i jednocze- 
śnie dystansuje się wobec wszystkich innych odbiorców, odmawiając im nawet tytułu fana, o ile nie spełniają bardzo konkretnych kryteriów. Moffat staje się doskonałym przykładem wybiórczego podejścia przemysłu kulturowego nie tylko do praktyk fanowskich, ale też do samych tekstów, których nie pasujące do oficjalnej franczyzy elementy ulegają przemilczeniu i deprecjacji w dalszej re-produkcji. Z kolei status E. L. James ujawnia funkcjonowanie podwójnych standardów w odniesieniu do fanów i fanek. Z perspektywy przemysłu kulturowego fani są gwarancją podtrzymania jakości treści popkulturowych, fanki zaś jakość tę obniżają; fani stają się profesjonalnymi twórcami, a fanki się sprzedają; fani dążą bezkompromisowo do realizacji swojej wizji artystycznej, fanki mają obsesje na punkcie kontroli (s. xix). Pełnia performatywnego wymiaru autorstwa w jego funkcji władzy nadawania znaczenia uwidacznia się w aktywności J. K. Rowling w mediach społecznościowych, której celem jest sprawowanie absolutnej kontroli nad znaczeniem i interpretacją wśród odbiorców. Jest to przykład autorstwa, które nie godzi się na funkcjonowanie w post-Barthesowskim świecie pluralizmu interpretacyjnego.

Filmografia i działalność Kevina Smitha prezentują inny ciekawy przypadek korelacji pomiędzy tożsamością fanowską a autorską, wskazujący na konieczność dystansowania się autora-fana wobec tożsamości fanowskiej w celu profesjonalizacji swojej kondycji, w równej mierze, w jakiej dąży się do ustanowienia powiązania danego twórcy $\mathrm{z}$ fandomem. Okazuje się zatem, że pozycja autora-fana opiera się na kruchej równowadze pomiędzy aspektem fanowskim a autorskim, co też świadczy o tym, że nobilitacja fanów w przemyśle kulturowym ma jedynie pozorny charakter i jest zależna przede wszystkim od ekonomicznego potencjału odbiorców.

Analiza działalności Jossa Whedona uwzględnia z kolei fakt, że jego aktywność opiera się na podwójnym performansie: autorstwa i progresywnej polityki. Performatywny feminizm Whedona stał się marką, za pomocą której odgrywa on swoje autorstwo, co umożliwia wykorzystanie „fandomowej pracy” (s. xx) i ekonomiczną eksploatację fandomu, zamaskowaną jako polityczny aktywizm (finansowe wspieranie Whedona było uznawane za jednoznaczne $\mathrm{z}$ aktywizmem politycznym i działaniem na rzecz zmiany społecznej). Kultowa wręcz pozycja Zacka Snydera stanowi natomiast dobitny przykład sytuacji męskiego i toksycznego fandomu (patofandomu) we współczesnym krajobrazie medialnym. Postawy fanowskie, które wczesne fan studies określały jako anomalie, obecnie stały się tak powszechnymi modelami „bycia fanem”, że głównonurtowy twórca jest w stanie wykreować w oparciu o nie swoją tożsamość fanowską i uczynić z nich narzędzie marketingowe. Sytuacja taka wskazuje na to, że należy gruntowanie przemyśleć dotychczasowe ustalenia fantropologii i zmienić perspektywę badań, zwracając się w stronę przez długi czas pomijanych i przemilczanych aspektów działalności fanowskiej, określanych zbiorczo jako „toksyczny fandom” (toxic fandom) czy patofandom.

Ostatnie case study poświęcone jest tym twórcom, którzy z racji swojej niskiej pozycji społecznej wynikającej z istniejących nierówności, pomimo związków 
z fandomami i okazyjnie przyjmowanych tożsamości fanowskich nie uzyskali takiej nobilitacji, jak osoby we wcześniej omawianych przypadkach. Patty Jenkins, Ryan Cooler, Taika Waititi, siostry Wachowskie i Ava DuVernay dostarczają przykładów niezwykle ambiwalentnej relacji z fanami, a zarazem są świadectwem istnienia w społecznościach fanowskich uprzedzeń na tle płciowym, rasowym i seksualnym. Etykietka autora-fana stanowi gwarancje jakości i afektywnego przywiązania, ale obwarowana jest licznymi kulturowymi wymogami i warunkami, przede wszystkim dotyczącymi koloru skóry i tożsamości płciowej oraz seksualnej, które wyznaczają także parametry „poprawnego” fana. Co więcej, w przypadku autorów niespełniających tych wymogów, autoidentyfikacja $\mathrm{z}$ fanami odbywa się kosztem zakwestionowania ich profesjonalizmu, co też ujawnia warunkowe przyjęcie fana w obręb kultury głównonurtowej.

Salter i Stanfill nie bez powodu odwołują się w tytule monografii do pojęcia auteura, spopularyzowanego przez francuską Nową Falę z jej polityką autorstwa, której celem była nobilitacja twórczości filmowej, nadanie jej rangi działalności artystycznej. Formułowana w tej perspektywie polityka jawnie wskazywała na konstruktywistyczny i performatywny wymiar autorstwa oraz jego społeczne funkcje. Obecna tendencja w przemyśle popkulturowym stanowi rewitalizację tego podejścia jako podstawowej strategii marketingowej, która okazuje się konieczna w dobie kulturowej konwergencji. Pozorna fano-centryczność współczesnej popkultury doprowadziła do wyłonienia się nowego archetypu autora jako fana, dokładając kolejne warstwy perfomansu do już funkcjonujących. Dotychczas autor był celebrytą, osobą publiczną (być może społecznie zaangażowaną), natchnionym podmiotem twórczym; obecnie staje się też fanem, definiowanym przez afektywny związek z produkowanymi treściami. Salter i Stanfill dokładnie analizują mechanizm powstawania nowego typu autorstwa oraz jego kulturowe, tekstowe i przemysłowe zaplecze. Prezentowane przez nie analizy są wielowątkowe i wnikliwe, obejmują konstrukcje podmiotu autorskiego oraz jego recepcję na przestrzeni lat, warunki, jakie spełnić muszą popkulturowi twórcy, aby skutecznie rościć sobie prawo do autorstwa i fanowstwa, a także działania, jakie podejmują autorzy, by podtrzymać ten złożony status. W efekcie otrzymujemy najbardziej aktualny obraz autorstwa medialnego we współczesnych badaniach z tego obszaru. Omawiana praca stanowi więc obowiązkową lekturę dla medioznawcówów, przedstawicieli krytyki feministycznej, fantropologów oraz wszystkich badaczy podejmujących studia nad autorstwem.

\section{BIBLIOGRAFIA}

Salter, A., \& Blodgett, B. (2017). Toxic geek masculinity in media: Sexism, trolling, and identity policing. Springer.

Stanfill, M. (2019). Exploiting fandom: How the media industry seeks to manipulate fans. Iowa City: University of Iowa Press. 